RUNNING HEAD: PRACTITIONERS' USE OF DRAWING DURING INTERVIEWS

Police officers' and Registered Intermediaries' use of drawing during investigative interviews with vulnerable witnesses

Michelle L. A. Mattison

Department of Psychology, University of Chester, Chester, U.K.

Coral J. Dando

Department of Psychology, University of Westminster, London, U.K.

Corresponding author:

Dr Michelle L. A. Mattison

Department of Psychology, University of Chester, Parkgate Road, Chester, CH1 4BJ, U.K.

Email: m.mattison@chester.ac.uk 
RUNNING HEAD: PRACTITIONERS' USE OF DRAWING DURING INTERVIEWS

\title{
Police officers' and Registered Intermediaries' use of drawing during investigative interviews with vulnerable witnesses
}

\begin{abstract}
Attempts to enhance episodic retrieval focus largely on verbal strategies which do not always address the limited or impaired free recall ability of vulnerable witnesses. Asking a witness to draw while recalling episodic information has long been deemed an effective method of improving communication and cognitive performance. Thus far, research has revealed these effects within laboratory settings but with scarce attention paid to real-life interview practice. In this paper, we explore police officers' and Registered Intermediaries' use of drawing during investigative interviews with vulnerable witnesses. A sample of specialist practitioners $(n=85)$, comprising of vulnerable witness interviewing police officers $(n=50)$ and Registered Intermediaries $(n=35)$ completed a self-report questionnaire. As expected, frequent use of drawing was reported by both practitioner groups, and there was a positive correlation between reported use and perceived effectiveness. There were similarities between groups in reported techniques employed when using drawing, but some differences were apparent and these were attributed to the differing functions in police and Registered Intermediary roles. Overall, a consensus between empirical research and practice is evident, but these findings warrant further exploration in order to establish whether such practice is wide-spread.
\end{abstract}

\section{Keywords:}

Drawing; sketching; vulnerable witnesses; intermediaries; investigative interview. 
RUNNING HEAD: PRACTITIONERS' USE OF DRAWING DURING INTERVIEWS

\section{Introduction}

In England and Wales, all victims and witnesses ${ }^{1}$ under the age of 18 are considered as vulnerable because they are cognitively and psychological less developed than adults (Youth Justice and Criminal Evidence Act, 1999), and so the interview techniques deemed appropriate for supporting typically developed adults to provide best evidence are not ordinarily appropriate for children (Pipe, Lamb, Orbach \& Esplin, 2004; Murphy \& Clare, 2006). Accordingly, investigative interviews with children are guided by the Ministry of Justice Achieving Best Evidence (ABE; Ministry of Justice, 2011), which advocates the use of developmentally appropriate interview techniques, with an emphasis on the use of open questioning styles. Open questions are good because they are interviewee focused, allow children to tell about their experiences without interruption (Fisher, 1995; Poole \& Lamb, 1998; Wolfman, Brown \& Jose, 2016; Wright \& Powell, 2006), and eyewitness research has consistently demonstrated that the most accurate recall materialises when witnesses provide uninterrupted accounts in their own words (Lamb, Orbach, Hershkowitz, Esplin \& Horowitz, 2007; Lamb, LaRooy, Malloy \& Katz, 2011; Milne \& Bull, 2006).

However, memory for personally experienced events fundamentally relies on the capacity to bind features of an experience into an integrated episodic representation (e.g., Eichenbaum \& Cohen, 2001; Tulving, 1985). Memory binding and encoding abilities are underdeveloped in children (Howe \& O'Sullivan, 1997; Lee, Wendelken, Bunge, \& Ghetti, 2016; Sluzenski, Newcombe \& Kovacs 2006), which means that they typically recall less episodic information than adults because of reduced binding mechanisms. Equally, children tend to employ less-exhaustive retrieval strategies than adults, which reduces episodic recall performance still further (Barlow, Jolley \& Hallam, 2011; Brainerd, Reyna, Howe \& Kingma, 1990; Buckatko \& Daehler, 1998; Lloyd, Doydum \& Newcombe, 2009; Salmon,

\footnotetext{
${ }^{1}$ Including both onlookers and victims of crime.
} 
RUNNING HEAD: PRACTITIONERS' USE OF DRAWING DURING INTERVIEWS

2001). Children also generally recall less episodic information in response to open questions (Arnold \& Lindsay, 2002; Gee \& Pipe, 1995; Hershkowitz, Lamb, Orbach, Katz, \& Horowitz, 2012, Paz-Alonso, Ghetti, Matlen, Anderson, \& Bunge, 2009), because open questions, such as 'tell me everything you remember about..." dictate multiple word responses, and offer almost no interviewer guided retrieval support. It may be that these challenges are recognised by interviewers, thus resulting in limited improvement over time in the quality of questions asked of children, particularly in child sexual abuse cases (see Criminal Justice Joint Inspection, 2014; Johnson et al., 2015). Although, with age, children's episodic responses to open invitations improves, and so less interviewer-guided support is required, all children can benefit from external retrieval support (see Brown \& Lamb, 2015).

For children with additional needs, such as learning disability or developmental disorder, many of whom often present with a distinct communication and memorial profile, free recall performance is typically further reduced (Brown, Brown, Lewis, \& Lamb, 2018; Boucher, 1981; Boucher \& Lewis, 1989; Bowler, Gaigg, \& Lind, 2011; Millward, Powell, Messer \& Jordan 2000; Wyman, Lavoie, \& Talwar, 2018), and tends not to improve with age, and so they continue to need retrieval support. For interviewers, reduced freely recalled event information inevitably means the production of less information (fewer topics and source items) to probe during the follow-up questioning phase. While 'what' and 'how' questions have been shown to be productive in children's accounts of actions (Ahern, Andrews, Stolzenberg \& Lyon, 2018), reduced free recall increases the likelihood that interviewers will use fewer appropriate (i.e., closed prompt) questions in an attempt to collect event information (Powell, Fisher \& Wright, 2005; Wright \& Powell, 2006), thus compromising recall accuracy. Indeed, children with atypical development are more likely to be interviewed using inappropriate questions, such as closed, suggestive, and leading (Brown, Lewis, Stephens, \& Lamb, 2017; Cederborg \& Lamb, 2008). 
RUNNING HEAD: PRACTITIONERS' USE OF DRAWING DURING INTERVIEWS

Because interviewers seldom interview children with no knowledge of what has been alleged, not only do closed questions limit opportunities for children to provide a full account, they can, inadvertently, facilitate interviewer confirmation bias (Powell, HughesScholes \& Sharman, 2012). Accordingly, the challenges of gathering best evidence from children whose free recall ability is still developing, or is impaired, has encouraged researchers to seek alternative, developmentally appropriate interviewer-guided retrieval support, which does not compromise the resultant information for the purposes of the criminal justice system.

\section{External Retrieval Support}

Practitioners in clinical settings have long reported that the use of art media such as drawing, can address the disconnect between what children know and understand, and what they express verbally (Driessnack, 2005). Research investigating the use of drawing in forensic settings has, in the main, produced positive and encouraging findings. For instance, completeness and accuracy of the information elicited is improved when children are invited to draw about what happened while being asked open questions (Butler, Gross \& Hayne 1995; Gross \& Hayne, 1999; Macleod, Gross, J \& Hayne, 2016, Salmon et al., 2003, Gross \& Hayne, 1999, Salmon, Roncolato \& Gleitzman, 2003), and the act of drawing during interviews has been found to aid communication about traumatic events (Katz \& Hamama, 2013).

More specifically, when used at first retrieval research has found a positive effect of drawing for typically developing children and children with autism (Mattison, Dando \& Ormerod, 2015; 2018). Here, drawings remained visible throughout the interview, and the positive effect of drawing and being able to refer back to that drawing carried over to the probed recall phase of an interview, again resulting in improved performance (Mattison et al., 
RUNNING HEAD: PRACTITIONERS' USE OF DRAWING DURING INTERVIEWS

2018). Conversely, when drawing was not used during the first interview/retrieval attempt, the beneficial effects for children with and without autism were less apparent (Henry et al., 2017. For further discussions, see Dando et al., 2018; Henry et al., 2018). While no negative effect on recall was found in Henry et al's (2017) study, the absence of improved recall is attributed to two factors. First, age differences between groups, where Mattison et al's (2015, 2018) participants were approximately one year younger, and secondly, the delay between event and recall was substantially shorter.

Nonetheless, the benefits of asking children to draw while recalling episodic events are evident in the broader literature. We attribute this to two reasons. First, because much of the information that children encode is sensory and perceptual, child witnesses require a precise retrieval cue and memory store match (Ackerman, 1985; Bjorklund, 1987; Salmon, 2001). Drawing allows children to generate their own retrieval cues; cues that are salient and child-led. Generating salient retrieval cues, as advocated by the principles of encoding specificity (Tulving \& Thomson, 1973), can prompt recall of further details, while also aiding the structure of children's free recall narrative (Butler et al., 1995; Wesson \& Salmon, 2001; Patterson \& Hayne, 2011). Second, drawing can reduce the social pressure associated with interviewer-interviewee interactions due to the shift in focus to the drawing, rather than on the interviewee (Pipe \& Salmon, 2009) - a factor that is particularly pertinent to some especially vulnerable witnesses, such as children with autism, for example (White, Oswald, Ollendick \& Scahill, 2009). Shifting the onus of responsibility from the interviewer to the child could potentially lower the well-known effects of anxiety on cognition and performance (see Eysenck, 1992 and Eysenck, Derakshan, Santos, \& Calvo, 2007).

Drawing builds upon the child's abilities (rather than limitations) by creating an environment in which it is possible to optimally report events in an augmented fashion (Barlow et al., 2011; Saywitz, 1995). Crucially, recall accuracy reduces when children are 
RUNNING HEAD: PRACTITIONERS' USE OF DRAWING DURING INTERVIEWS

not instructed to draw about the event in question, and are thus provided with no instructions (Macleod et al., 2016). Similarly, the use of communication aids such as drawing, does not negate the use of appropriate questioning styles. Indeed, recent research has suggested that interviewers commonly use 'wh' questions, instead of open questions, alongside the use of props (Wolfman, Brown \& Jose, 2018), and it is clear that drawing does not protect children from the effects of leading of suggestive questions (Bruck, Melnyk, \& Ceci, 2000; Gross, Hayne, \& Poole, 2006; Strange, Garry, \& Sutherland, 2003).

\section{Interviewing children: practice and procedure}

The most prominent recommendation in ABE (2011) is that interviewers adopt a phased approach to interviewing, which commences with a free recall account of a topic followed by questioning phase (a probed recall based upon the information provided in the free recall account). ABE (2011) also recommends additional strategies, such as assessment and facilitation of an interview by a Registered Intermediary, and the use of props, as appropriate (with or without an intermediary) (ABE, 2011).

Registered Intermediaries are professionals who, since 2004, have been utilised across the criminal justice system in England and Wales to enable vulnerable witnesses to give their best evidence (Victims' Commissioner, 2018). Recruited from areas such as speech and language therapy, psychology, education, and mental health, Registered Intermediaries are appointed by the Ministry of Justice and trained to apply their communication skills within the criminal justice system. The purpose of the role is to facilitate commiunication with vulnerable witnesses; one of a number of 'Special Measures' outlined in the Youth Justice and Criminal Evidence Act 1999. During police investigations, Registered Intermediaries conduct a communication assessment of the vulnerable witness, before advising police interviewers on questioning techniques appropriate for that particular witness. Such advice 
RUNNING HEAD: PRACTITIONERS' USE OF DRAWING DURING INTERVIEWS

may include strategies for the phrasing and pacing of questions, the frequency and timing of breaks, and in the use of communication aids or props such as drawing (see Cooper \& Mattison, 2017; Registered Intermediaries Procedural Guidance Manual; RIPGM, 2015). Similar intermediary schemes exist outside of England and Wales, for instance in Northern Irleand and Australia (see Cooper \& Mattison, 2017 for a review).

In addition to police interviewing guidance, the Youth Justice and Criminal Evidence Act 1999 also makes provision for the use of props within court settings. Here, the 'Special Measure' - Aids to Communication - stipulates that vulnerable witnesses may be provided with a 'device' considered appropriate by the court to enable questions or answers to be communicate to, or by, the witness. Additional reference to the provision of props is made in other areas of relevant law in England and Wales, and also in the Advocate's Gateway 'toolkits' (a free, online resource) where research and good practice case examples are disseminated to barristers, judges and police officers. Toolkits published by the Advocate's Gateway have been cited with approval in the Criminal Practice Directions, the Court of Appeal Criminal Division, and in three intermediary practitioner procedural guidance manuals across the world - which means that practitioners are directed to refer to the guidance when working with vulnerable victims and witnesses, both in England and Wales, and internationally. It is likely that Registered Intermediaries operating in England and Wales will make use of such guidance (including ABE, 2011), and therefore incorporate the use of props, such as drawing, into their practice.

\section{The current study}

While the cognitive benefits of drawing have been well-documented in laboratory studies, actual use in real-world practice has received only modest attention. In the available body of work that has been published about interviewer behaviour (more broadly), important 
RUNNING HEAD: PRACTITIONERS' USE OF DRAWING DURING INTERVIEWS

insights about interviewers' perceptions and behaviour have been revealed. For instance, Wheatcroft, Wagstaff and Russell (2014), after surveying 33 specialist interviewing police officers, identified the need for simplified interview protocols to be developed - aimed specifically at those working in complex operational contexts, such as with vulnerable witnesses. Similarly, despite utilising a modest sample size of eight police officers, Wright and Powell (2006) were able to discover the basis for police officers' underutilisation of open questions. Other studies have explored different aspects of interviewers' practice, and indeed, one recent study has explored New Zealand police officers' use of visual aids (Wolfman et al, 2018), but to our knowledge, no research has explored whether, in England and Wales, practitioners' (including Registered Intermediaries') interview behavior is congruent with empirical findings specifically in relation to the use of drawing.

The aim of the current study is to address this significant gap in knowledge and understanding, particularly with reference to Registered Intermediaries. Here, we conducted a preliminary exploration of police officers' and Registered Intermediaries' perceptions and use of drawing during interviews with vulnerable witnesses in England and Wales. We predicted that, based on current available guidance in England and Wales (e.g., ABE, 2011, Advocate's Gateway Toolkits), a large proportion of practitioners' would utilise drawing. We also predicted that there would be a positive relationship between frequency of use and perceived efficacy. 
RUNNING HEAD: PRACTITIONERS' USE OF DRAWING DURING INTERVIEWS

\section{Method}

\section{Participants and Procedure}

Upon receiving ethical approval for study, we recruited two groups of practitioner participants: (i) specialist vulnerable witness interviewing police officers and (ii) Registered Intermediaries. Police officers from 11 forces across England and Wales were invited to take part in the study during a national continuing professional development event held in the North West of England. At a later date, an email invitation was disseminated by their respective force. Registered Intermediaries were invited to participate in the study during a national continuing professional development event held in the South of England.

Fifity police officers were recruited $(n=50)$, with all confirming that they were trained to the required level for interviewing vulnerable witnesses. At the time of data collection, the training spanned 15 days and was delivered to small groups of eight, during which they learn the relevant theory, before putting theory into practice by interviewing different types of vulnerable interviewees (played by actors and actresses). Police officers have to complete a series of intensive practice based assessments to pass this course. Despite passing the aforementioned course, nine of the 50 respondents indicated that they had not yet conducted any interviews with children or vulnerable adults post training, and so were excluded from anayses. Hence, the final sample of police officers comprised 41 respondents with a mean service of 19.40 years ( $S D=118.21$ months). Of those included in the analyses, police officers reported that they conduct a mean of 1.28 vulnerable witness interviews per week, with an overall mean of $109.08(S D=169.51)$ child interviews during their police career, to date. Twenty-seven $(65.9 \%)$ police officers reported having worked with a Registered Intermediary in a mean of $5.89(S D=5.91)$ cases.

The thirty-five Registered Intermediaries ( $n=35$; approximately $30 \%$ of the population of active Registered Intermediaries in England and Wales at the time of the study) were 
RUNNING HEAD: PRACTITIONERS' USE OF DRAWING DURING INTERVIEWS

recruited. Respondents had been working in their Registered Intermediary role for a mean number of 3.3 years $(S D=38.74$ months $)$. Seven intermediaries $(20 \%)$ reported that they had attended $\mathrm{ABE}$ interview training courses (as outlined above), while $80 \%$ reported they had received no investigative interview training outside of their Ministry of Justice Intermediary training. Further, the sample of intermediaries reported that they had facilitated communication in an overall mean number of 66.97 cases $(S D=72.32)$, overall, of which a mean of $55.92(S D=59.56)$ were investigative interviews conducted by police officers.

An electronic questionnaire was used to gather data for this research. Prior to providing infomed consent and completing the questionnaire, all participants were provided with information about the purpose of the study, namely, its aim to explore perceptions and use of drawing when interviewing vulnerable victims and witnesses. Participants were assured of anonymity, and informed of their right to withdraw at any point prior to data analyses. Participants received no payment.

\section{Materials}

Two questionnaires were developed for this study. The questionnaires differed between groups because of the different roles and responsibilities of police officers and Registered Intermediaries during an investigative interview - police officers conduct interviews while intermediaries facilitate.

Both questionnaires comprised open and closed questions (with free text and likert scale response options where appropriate), thus producing both quantitative and qualitative forms of data. Although the authors of the questionnaires (and this paper) include a former police officer and a practicing Registered Intermediary, draft pilot questionnaires were distributed to five police officers and five Intermediaries in order to achieve clarity and validity. The wording of the questionnaires was amended according to feedback received. 
RUNNING HEAD: PRACTITIONERS' USE OF DRAWING DURING INTERVIEWS

The final questionnaires for both groups of respondents were divided into two separate sections, described below:

(i) About you and your experience of working with vulnerable people

Respondents were asked to provide details about their professional training and general interviewing experience. Police officers were asked about their length of service and their level of investigative interview training. Officers also answered questions about their interviewing experience, such as how many victim and witness interviews they conduct per week; whether or not they conduct interviews with vulnerable victims and witnesses, and if so, how many. In addition, officers were asked about their interviewing experiences with particular groups of vulnerable witnesses, such as children, vulnerable adults and people with disabilities and / or developmental impairments. Finally, officers were asked to give details about their experiences of working with intermediaries during investigative interviews.

For the Registered Intermediaries, the first section of the questionnaire asked for information about their main occupation and details about their work as a Registered Intermediary, such as how long they have worked in that capacity; what geographical region(s) they work in; how many cases in total they have been appointed to; and what groups of vulnerable people they specialise in working with. Additionally, Registered Intermediaries were asked to list any investigative interview training courses that they had attended. Respondents were then asked to answer questions about their experiences of facilitating communication during police interviews, in particular, how many interviews they have facilitated as an intermediary. 
RUNNING HEAD: PRACTITIONERS' USE OF DRAWING DURING INTERVIEWS

(ii) Your use of drawing

The second section focused upon respondents' experiences and perceptions of using drawing during investigative interviews. Here, respondents were asked to provide detail about the manner by which they use drawing (if at all). Specific areas of focus were: (i) the frequency that drawing is used; (ii) when is drawing is used; (iii) how is drawing used; (iv) why drawing is used; and (v) how effective drawing is perceived to be. These results are the focus of this study.

\section{Analysis Approach}

Quantitative data were analysed using inferential statistical methods, employing a series of $t$-tests and Spearman's rank correlation coefficient. Qualitative data were analysed using qualitative content analysis. Here, responses to open-ended questions were examined for commonalities and coding categories were created directly and inductively (Elo \& Kyngas, 2008; Zhang \& Wildemuth, 2009). Results are reported for each of our two practitioner groups, and where appropriate, between group analyses and comparisons are carried out. 
RUNNING HEAD: PRACTITIONERS' USE OF DRAWING DURING INTERVIEWS

\section{Results}

Following questions about work experience and training, practitioners were asked whether or not they had ever used communication aids or props in their practice (During an interview with a vulernable witness, have you ever used any props or communication tools (e.g., sketching/drawing materials; post-it notes; symbols; dolls)?). Thirty-six police officers and 22 Registered Intermediaries stated that, yes, they had used props or communication aids (with the remainder either stating 'no', 'not sure' or 'prefer not to say').

Practitioners who stated that they had used communication aids or props during an interview with a vulnerable witness, were then asked to indicate on a likert scale ranging from 1 (never) to 5 (always), how frequently they use this tool. A total of 58 practitioners responded to this question, with the majority reporting that they use drawing 'often'. Table 1 displays police officers' and Registered Intermediaries' percentage responses for the frequency that drawing is used. A $t$-test revealed no significant difference between the two groups, $t(57)=.344, p=.304$. 
RUNNING HEAD: PRACTITIONERS' USE OF DRAWING DURING INTERVIEWS

Table 1. Police officers' and Registered Intermediaries' response rate for the frequency of use of drawing during investigative interviews with vulnerable witnesses.

\begin{tabular}{|c|c|c|c|c|c|c|}
\hline Group & $\begin{array}{l}\text { Never } \\
(1)\end{array}$ & $\begin{array}{c}\text { Rarely } \\
\text { (2) }\end{array}$ & $\begin{array}{l}\text { Often } \\
(3)\end{array}$ & $\begin{array}{c}\text { Almost } \\
\text { Always } \\
(4)\end{array}$ & $\begin{array}{c}\text { Always } \\
\text { (5) }\end{array}$ & $\begin{array}{l}\text { Mean } \\
\text { (SD) }\end{array}$ \\
\hline $\begin{array}{l}\text { Police officers } \\
(n=36)\end{array}$ & $0.0 \%$ & $\begin{array}{c}25.0 \% \\
(n=9)\end{array}$ & $\begin{array}{l}38.9 \% \\
(n=14)\end{array}$ & $\begin{array}{l}33.3 \% \\
(n=12)\end{array}$ & $\begin{array}{l}2.8 \% \\
(n=1)\end{array}$ & $\begin{array}{l}3.14 \\
(.83)\end{array}$ \\
\hline $\begin{array}{l}\text { Registered } \\
\text { Intermediaries } \\
(n=22)\end{array}$ & 0.0 & $\begin{array}{l}9.1 \% \\
(n=2)\end{array}$ & $\begin{array}{l}50.0 \% \\
(n=11)\end{array}$ & $\begin{array}{c}36.4 \% \\
(n=8)\end{array}$ & $\begin{array}{l}4.5 \% \\
(n=1)\end{array}$ & $\begin{array}{l}3.36 \\
(.72)\end{array}$ \\
\hline Total $(n=58)$ & 0.0 & $\begin{array}{l}19.0 \% \\
(n=11)\end{array}$ & $\begin{array}{l}43.1 \% \\
(n=25)\end{array}$ & $\begin{array}{l}34.5 \% \\
(n=20)\end{array}$ & $\begin{array}{l}3.4 \% \\
(n=2)\end{array}$ & $\begin{array}{l}3.22 \\
(.79)\end{array}$ \\
\hline
\end{tabular}

When is drawing used?

Practitioners were asked: "Please explain WHEN (during what stages) you use sketching/drawing during the interview? For example, at the beginning before rapport building, or throughout the entire interview?" A free text response resulted in fifty-five practitioners (33 police officers and 22 Registered Intermediaries), reporting that, rather than using drawing only during a particular phase of an interview (rapport, free narrative, questioning), they use drawing at various points based upon the individual witness' needs. These responses were coded into categories: (i) generally throughout the interview; (ii) to aid questioning / clarify key points; and (iii) only when necessary for the interviewee. Table 2 displays responses as a function of category and practitioner group. 


\section{RUNNING HEAD: PRACTITIONERS' USE OF DRAWING DURING INTERVIEWS}

Table 2. Police officers' $(n=33)$ and Registered Intermediaries' $(n=22)$ responses for the points when drawing is used during interviews with vulnerable witnesses.

\begin{tabular}{|c|c|c|}
\hline Category & Group and frequency $(n)$ & Example responses \\
\hline \multirow[t]{2}{*}{$\begin{array}{l}\text { Generally, throughout } \\
\text { entire interview }\end{array}$} & Police Officers $(n=18)$ & $\begin{array}{l}\text { - "As and when identified appropriate, no set rule." } \\
\text { - "Throughout the interview" } \\
\text { - "Throughout the interview when the interviewee mentions something that can be better } \\
\text { described through sketching." }\end{array}$ \\
\hline & $\begin{array}{l}\text { Registered Intermediaries } \\
(n=9)\end{array}$ & $\begin{array}{l}\text { - "during the interview I recommend it throughout, as and when it seems appropriate" } \\
\text { - "Throughout the interview" } \\
\text { - "During the interview I recommend it as and when it seems appropriate." }\end{array}$ \\
\hline \multirow[t]{2}{*}{$\begin{array}{l}\text { To aid questioning / clarify } \\
\text { key points }\end{array}$} & $\begin{array}{l}\text { Police Officers } \\
(n=10)\end{array}$ & $\begin{array}{l}\text { - "...throughout the interview when victim is explaining about a place location, or even drawing } \\
\text { of what they have seen." } \\
\text { - "During account clarification", } \\
\text { - "Only if the questioning cannot gain the verbal detail." }\end{array}$ \\
\hline & $\begin{array}{l}\text { Registered Intermediaries } \\
(n=9)\end{array}$ & $\begin{array}{l}\text { - "During questioning when asked to describe location, witness could draw room layouts and } \\
\text { - "Wlso for description of stolen items, witness able to draw design on jewellery" } \\
\text { - "during the interview to help very young children sequence events or describe a room or } \\
\text { place." }\end{array}$ \\
\hline \multirow[t]{2}{*}{$\begin{array}{l}\text { Only when necessary for } \\
\text { the interviewee }\end{array}$} & $\begin{array}{l}\text { Police Officers } \\
(n=3)\end{array}$ & $\begin{array}{l}\text { - "First I build rapport and when the witness has started telling and I notice that he/she has } \\
\text { problems/difficulties in explaining or recalling, I can suggest that he/she use drawing." } \\
\text { - "Only when it appears necessary, usually during the victim or witnesses account"” } \\
\text { - "In interview - child wanted to draw what she was explaining." }\end{array}$ \\
\hline & $\begin{array}{l}\text { Registered Intermediaries } \\
(n=4)\end{array}$ & $\begin{array}{l}\text { - "At points where is clear the VW [vulnerable witness] is finding it difficult to verbally explain" } \\
\text { - "It depends on the witness and how much this might be needed and what for." } \\
\text { - "Dependent on individual need - usually part way through." }\end{array}$ \\
\hline
\end{tabular}


RUNNING HEAD: PRACTITIONERS' USE OF DRAWING DURING INTERVIEWS

\section{How is drawing used?}

Respondants who reported that they use drawing, were asked: "Please explain HOW you use sketching/drawing during investigative interviews. For example, what do you say, and what types of drawing equipment do you use?" These open responses were coded into the following categories: (i) general instructions (free drawing); (ii) specific instructions (directed drawing); (iii) and drawing on a body outline, with some respondants reporting use of multiple methods. Figure 1 displays the types of instructions provided by practitioners as a function of professional role.

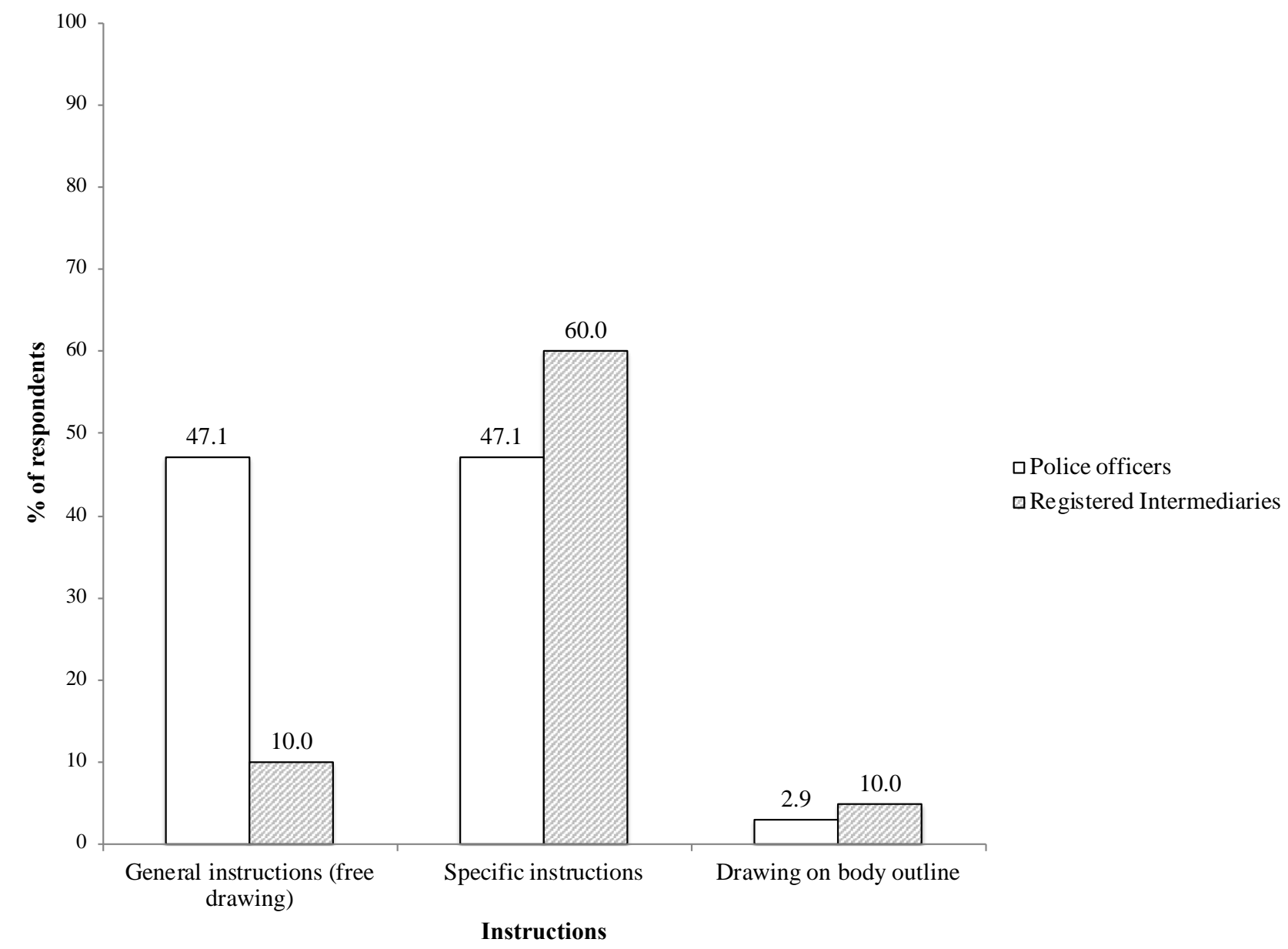

Figure 1.

Police officers' and Registered Intermediaries' percentage response rate for how drawing is used. 
RUNNING HEAD: PRACTITIONERS' USE OF DRAWING DURING INTERVIEWS

Almost half of police officers claimed that they provide general instructions that allowed the interviewee to free draw. For example, three stated that they say to interviewees "please draw everything that you can remember", "draw what happened next" "picture in mind, draw everything can remember, take time, leave nothing out." The same number of police officers also reported that sometimes they provide specific instructions that encourage the interviewee to draw particular objects, people or locations, and labels. For example, one police officer reported "I would just ask for a basic drawing...to point out the location of objects in a room for example, i.e., the bed in relation to the door to the bedroom.", while another stated "I would ask them to draw in as much detail as possible and to label different parts of the diagram. I would let them finish and then ask them questions based on the drawing." One officer reported that he /she asks interviewees to draw on a body outline or map.

Two Registered Intermediaries reported that they that they provide general instructions that allowed the interviewee to free draw, with the majority $(n=12)$ claiming that they provide specific instructions to interviewees. One intermediary stated that he / she asks interviewees to draw on a body outline or map "draw on a body outline 'show me where'.")

Two additional categories were created, specific to the responses provided by Registered Intermediaries: (i) officer provides instructions and (ii) no instructions provided. Six intermediaries $(30.0 \%)$ stated that the interviewing officer provides drawing instructions. One intermediary (5\%) reported that she does not provide instructions, as she is the person who draws based upon the account provided by the interviewee: "I do the drawing generally and show each drawing with an explanation of what it is e.g. 'you said you sat on the bed. Here you are on the bed'. Continue like this asking whether the picture goes before or after last drawn event and get witness to place picture in correct sequence on table. If witness draws it's usually a room plan or street plan." 
RUNNING HEAD: PRACTITIONERS' USE OF DRAWING DURING INTERVIEWS

\section{Why is drawing used?}

Practitioners were asked: "Please explain why you use sketching/drawing during interviews?" Via free text response, fifty practitioners (90.1\% of total sample) who claimed to use drawing during interviews, described particular reasons for their use of this tool, and these responses were analysed and coded into five categories, with some respondants citing multiple reasons: (i) aid communication, overall; (ii) assist with clarification / questioning; and (iii) enhance memory. Table 3 displays responses (per category) for why practitioners use drawing as a tool during interviews. 


\section{RUNNING HEAD: PRACTITIONERS’ USE OF DRAWING DURING INTERVIEWS}

Table 3. Police officers' ( $n=33)$ and Registered Intermediaries' $(n=19)$ responses for why drawing they use during investigative interviews with vulnerable witnesses

\begin{tabular}{|c|c|c|}
\hline Category & $\begin{array}{c}\text { Group and } \\
\text { frequency }(n)\end{array}$ & Example responses \\
\hline \multirow[t]{2}{*}{$\begin{array}{l}\text { Aid } \\
\text { communication, } \\
\text { overall }\end{array}$} & $\begin{array}{l}\text { Police } \\
\text { Officers } \\
(n=27)\end{array}$ & $\begin{array}{l}\text { "To describe where something may have happened when verbally it may be hard to explain." } \\
\text { "Another form of communication method of recovering evidence." } \\
\text { "Movements of people, vehicles etc or other objects can be difficult to put in words that the observer (jury or others) can clearly } \\
\text { understand what the witness is trying to explain. As a consequence, constructing the drawing/sketch as described brings the } \\
\text { verbal account alive and provides a picture to the observer." } \\
\text { "When answering questions, less focus on them [the interviewee], possibly less intense and less eye contact." }\end{array}$ \\
\hline & $\begin{array}{l}\text { Registered } \\
\text { Intermediaries } \\
(n=17)\end{array}$ & $\begin{array}{l}\text { "To enable a witness to explain something that they couldn't otherwise explain i.e. using just verbal means.” } \\
\text { "To help with sequencing and provide visual representation for interviewing officer." } \\
\text { "To help focus attention to provide a concrete reference for young children for time lines etc." }\end{array}$ \\
\hline \multirow[t]{2}{*}{$\begin{array}{l}\text { Assist with } \\
\text { questioning and } \\
\text { clarification }\end{array}$} & $\begin{array}{l}\text { Police } \\
\text { Officers } \\
(n=12)\end{array}$ & $\begin{array}{l}\text { "To assist in describing layouts." } \\
\text { "I feel it helps me to understand where and how things have happened whilst assisting the witness to describe } \\
\text { events/whereabouts/routes etc." } \\
\text { I find that they get a lot more detail and they're useful for probing questions and for clarification." }\end{array}$ \\
\hline & $\begin{array}{l}\text { Registered } \\
\text { Intermediaries } \\
(n=3)\end{array}$ & $\begin{array}{l}\text { "It may clarify something the witness is struggling to explain, may also provide more detail that might have been overlooked } \\
\text { when just a verbal record was given." } \\
\text { "It clarifies muddled sequences of events and takes away the need to describe a room or route in words which the witness may not } \\
\text { have." }\end{array}$ \\
\hline \multirow[t]{2}{*}{ Enhance memory } & $\begin{array}{l}\text { Police } \\
\text { Officers } \\
(n=9)\end{array}$ & $\begin{array}{l}\text { "Puts the interviewee back in that time/place. It tends to slow down things for them so that their recollection is better." } \\
\text { "It usually enhances recall..." } \\
\text { "Assist in memory retrieval." }\end{array}$ \\
\hline & $\begin{array}{l}\text { Registered } \\
\text { Intermediaries } \\
(n=4)\end{array}$ & $\begin{array}{l}\text { "I would use it to provide a memory prompt..." } \\
\text { "The aim is not for her to produce drawings of events as evidence, the aim is to provide retrieval cues (to make her memories of } \\
\text { events more accessible, to scaffold her thinking and communication (freeing up space to be able to remember and explain)." }\end{array}$ \\
\hline
\end{tabular}




\section{RUNNING HEAD: PRACTITIONERS' USE OF DRAWING DURING INTERVIEWS}

\section{How effective is drawing?}

Respondents were asked to indicate, on a five-point rating scale (with 1 representing 'not at all' to 5 'always'), how effective they believe drawing to be. A $t$-test was performed to investigate whether the perceived effectiveness of drawing varied as a function of profession. There was no statistically significant difference between the two professional groups, $t(59)=$ $.791, p=.431$. To explore the data in more depth, Spearman's correlation coefficient was conducted.

There was a strong positive relationship between the perceived effectiveness of drawing and the frequency of use of drawing, $r_{s}(53)=.704, p=<.001$. Table 4 displays police officers' and intermediaries' percentage responses for perceived effectiveness of drawing during investigative interviews.

Table 4. Police officers' and Registered Intermediaries' percentage response rate for perceived effectiveness of drawing during investigative interviews with vulnerable witnesses.

\begin{tabular}{|c|c|c|c|c|c|c|}
\hline Group & $\begin{array}{l}\text { Not effective } \\
\text { at all (1) }\end{array}$ & $\begin{array}{c}\text { Not very } \\
\text { effective (2) }\end{array}$ & $\begin{array}{c}\text { Quite } \\
\text { effective (3) }\end{array}$ & $\begin{array}{c}\text { Very } \\
\text { effective (4) }\end{array}$ & $\begin{array}{c}\text { Always } \\
\text { effective (5) }\end{array}$ & Mean (SD) \\
\hline $\begin{array}{l}\text { Police officers } \\
(n=33)\end{array}$ & 0.0 & $\begin{array}{l}6.0 \% \\
(n=2)\end{array}$ & $\begin{array}{l}18.2 \% \\
(n=6)\end{array}$ & $\begin{array}{c}27.3 \% \\
(n=9)\end{array}$ & $\begin{array}{l}48.5 \% \\
(n=16)\end{array}$ & $4.21(.95)$ \\
\hline $\begin{array}{l}\text { Registered } \\
\text { Intermediaries } \\
(n=22)\end{array}$ & 0.0 & $\begin{array}{l}4.5 \% \\
(n=1)\end{array}$ & $\begin{array}{l}9.1 \% \\
(n=2)\end{array}$ & $\begin{array}{l}63.7 \% \\
(n=14)\end{array}$ & $\begin{array}{c}22.7 \% \\
(n=5)\end{array}$ & $4.05(.72)$ \\
\hline Total $(n=55)$ & 0.0 & $\begin{array}{l}5.5 \% \\
(n=3)\end{array}$ & $\begin{array}{c}14.5 \% \\
(n=8)\end{array}$ & $\begin{array}{l}42.0 \% \\
(n=23)\end{array}$ & $\begin{array}{l}38.0 \% \\
(n=21)\end{array}$ & $4.18(.82)$ \\
\hline
\end{tabular}


RUNNING HEAD: PRACTITIONERS' USE OF DRAWING DURING INTERVIEWS

Police officers were asked to state which particular group(s) of vulnerable witnesses they believed drawing to be most effective for (If applicable, please specify which group $(s)$ of vulnerable people you believe the sketching/drawing to be most effective for). Twenty-one police officers responded to this question, with six officers (28.6\%) stating that children benefit most from the use of drawing during interviews. Five police officers $(23.8 \%)$ reported that the effectiveness of drawing depends upon the witness and the circumstances. For example, one police officer stated "each interviewee is different, keep an open mind and use sketch plans if you feel they are appropriate.”, while another reported “depends on circumstances.” Four police officers (19.0\%) reported that drawing is effective with all vulnerable groups. For example, one police officer stated "anyone who it assists in describing something in interview."

Two police officers claimed that drawing is effective for anybody with capacity to draw. One of these officers stated "all persons taken on their ability to sketch or draw regardless of group e.g. I can interview an eight year old who can draw a really good plan of a room, then interview a thirty year old educated working person who is unable to draw any reasonable representation so groups don't come into it, it is the ability of the witness." Three police officers made reference to specific impairments. For instance, four police officers $(19.0 \%)$ claimed drawing is most effective for people with learning disability, and another police officer stated that drawing is most effective for people with autism ("with some autistic witnesses it assists in constructing a detailed chronological narrative").

Finally, Registered Intermediaries were asked, via a free text box, to provide additional information about their perceived use of drawing. Nine Registered Intermediaries responded. One Registered Intermediary stated that "it depends on what is being drawn, who by, and when and why, but generally it has been an invaluable tool." Another respondent claimed "drawing can be used at every level, from a mark on a body, to sophisticated diagram drawings of place/person/actions." Also, a Registered Intermediary who also reported that he / she 


\section{RUNNING HEAD: PRACTITIONERS' USE OF DRAWING DURING INTERVIEWS}

produces the drawings herself (rather than asking the witness to do so), stated that "it can get in the way of the fluency of an interview, interrupting the flow of question and answer or of thought process. Some events may be very tricky to draw, especially very detailed sexual imagery. Definitely a challenge for me as I don't draw well. Some witnesses e.g. ASD don't recognise the symbolism of a drawing e.g., a stick figure to represent a person, so there's no point using drawing. Emotions are difficult to convey through simplistic drawing."

\section{Discussion}

The current study explored police officers' and Registered Intermediaries' perceptions and use of drawing during investigative interviews with vulnerable witnesses. Based upon empirical research and guidance available to practitioners, we predicted that both groups were likely to use drawing during interviews with vulnerable witnesses, and that there would be a positive relationship between frequency of use and perceived efficacy.

Confirming the first prediction, it was apparent that drawing is a tool used frequently by both police officers and Registered Intermediaries, with no significant difference in reported frequency of use between these two professional groups. Practitioners also perceived drawing as being 'very effective' with no significant between-group differences. As one might expect, ratings of effectiveness corresponded with reported use of drawing. That is, those who reported using drawing frequently, also regarded it as highly effective. Perceived use and effectiveness may be a self-fulfilling prophecy, and the source of practitioners' knowledge about the use of drawing was not explored, but it is reasonable to suggest that it is the recommendations outlined within ABE (2011) and RIPGM (2015) that have been fundamental in promoting the use of drawing across both groups; particularly given that both the aforementioned publications are universally accepted as detailing 'gold standard' practice and form the basis of practitioner training, resepectively. That said, it is not necessarily the case 


\section{RUNNING HEAD: PRACTITIONERS' USE OF DRAWING DURING INTERVIEWS}

that best practice advice for conducting investigative interviews is always followed (Dando, Wilcock \& Milne, $2008^{\mathrm{a}} ; 2008^{\mathrm{b}} ; 2009^{\mathrm{a}}$ ), even when interviews are digitally recorded and so open to in-depth scrutiny. Hence, it appears likely that drawing is used largely because practitioners recognise its efficacy, which naturally promotes its use. What is unclear, and warrants further investigation, is whether or not perceived effectiveness corresponds with information gathered during real-life investigative interviews (as per research conducted in New Zealand - see Wolfman et al., 2018).

This study also explored when and how practitioners use drawing during investigative interviews. While there were some similarities in practice between groups, not surprisingly, differences did emerge. These differences can be attributed to the differing functions of each practical role, professional backgrounds, and training experience. For instance, police officers are not required to conduct a communication assessment prior to conducting an investigative interview with a vulnerable witness, thus they did not report to use drawing at this stage (as detailed by Registered Intermediaries). Conversely, a communication assessment conducted by a Registered Intermediary, and the subsequent report that is produced after the assessment takes place, forms the foundations of the Registered Intermediary's recommendations to the interviewing officer (and court, if necessary) (RIPGM, 2015). The communication assessment is therefore pivotal to Registered Intermediaries' role, thus providing an explanation as to why this group reports to use drawing during assessments. Despite some professional group differences being apparent, there was a consensus that this tool is used generally throughout interviews, and that it was used to aid the process of questioning as and when necessary. This finding relates to practitioners' comments concerning why they use drawing during interviews. The overarching reasons cited by respondents, was that drawing aids communication and enhances memory, which corresponds with findings from empirical research concerning the memorial benefits of drawing in investigative interviews. 
RUNNING HEAD: PRACTITIONERS' USE OF DRAWING DURING INTERVIEWS

Corresponding with when drawing is reportedly utilised, the results in this study suggest that both groups of practitioners provide specific instructions about what to draw, such as asking the interviewee to draw particular aspects of their account (e.g., 'please could you draw a map of the bedroom'). However, more police officers than Registered Intermediaries reported that they provide general instructions and encourage free drawing (e.g., 'please draw what happened'). Conversely, one Registered Intermediary reported that s/he produces the drawing herself and bases it upon the account provided by the witness. This statement of practise may go some way to support the claim by Krähenbühl (2011) that intermediaries may lack understanding with regard to leading questions and questioning formats used within investigative interviews. However, without further context of the case, it's not possible to fully attribute this instance with either appropriate or indeed inappropriate practise. Differences may also emanate from Registered Intermediaries' variable training and overall knowledge of interviewing strategies (Krähenbühl, 2011). Also noteworthy is the difference in functions between the two professional groups. For example, police officers' requirement to gather reliable evidence, and Registered Intermediaries role of facilitating the process - which inevitably may impact upon the ways in which communication aids are utilised. What is also not clear, is to what extent the sample of police officers were referring to their use of drawing in cases where they were working with a Registered Intermediary.

The use of communication aids such as drawing is at the discretion of the Registered Intermediary and interviewing police officer, and possibly dependent upon individual expertise and experience. The findings of an Registered Intermediary's communication assessment with a vulnerable witness will also dictate recommendations regarding the use of communication aids, and drawing may be only one of a range of tools and strategies assessed and later recommended. However, the Ministry of Justice does not stipulate the factors to be explored during the Registered Intermediary's communication assessment of a vulnerable witness. 


\section{RUNNING HEAD: PRACTITIONERS' USE OF DRAWING DURING INTERVIEWS}

Although the RIPGM (2015) does suggest a structure for the communication assessment report, the use of particular communication aids is not discussed extensively. Nonetheless, Registered Intermediaries are not always taught about empirical evidence and 'best practice' when using communication aids, and so we assume differences between police officers' and Registered Intermediaries' use of props during investigative interviews could be attributed to this. Lack of training that Registered Intermediaries receive on the topic of appropriate questioning during interviews, was an issue previously highlighted by Krähenbühl (2011). However, this does not explain the commonality between police officers' and Registered Intermediaries use of drawing.

Children were identified as witness groups that police officers believed drawing is most effective with. This is unsurprising given the previous research that has demonstrated the positive effects of drawing during investigative interviews (e.g., Barlow et al., 2011; Butler et al., 1995; Dando et al., 2009 ; 2011; 2013; Gross \& Hayne, 1999; Mattison et al., 2015; 2018; Salmon et al., 2003; Strange et al., 2003). In particular, it is known that children produce significantly more correct information when they are asked to draw and describe an event that they have witnessed, as opposed to just verbally describing it (Mattison et al., 2015; 2018; Salmon, 2001). The completeness and accuracy of accounts is also enhanced when children are asked to draw, provided that appropriate questioning methods are employed (Butler et al., 1995; Gross \& Hayne, 1999, Salmon et al., 2003). Similarly, with regard to people with autism, some studies have found that drawing can increase access to memory stores (Barlow et al., 2011; Mattison et al., 2015; 2018;), with reduced risk of memory contamination (Strange et al., 2003), although this has not always been the case (Henry et al., 2017). Police officers and Registered Intermediaries may be aware of the memorial benefits of drawing because empirical research findings may be included in training packages. Further analysis of the training content provided to these groups will indicate whether this is the case, however, recent examination of 
RUNNING HEAD: PRACTITIONERS' USE OF DRAWING DURING INTERVIEWS

criminal justice practitioner training suggests some disparity (Cooper et al., 2018). If drawing is a tool or strategy that is receommended, it is important to establish whether or not the limitations of this approach are highlighted to trainees, especially given the findings relating to the adverse effects of inappropriate questioning and lack of instructions (Bruck et al., 2000; Gross et al., 2006; Strange, et al., 2003; Wolfman et al., 2018).

Further, understanding the extent to which drawing may (or may not) be recommended alongside other communication aids, also warrants further investigation. Indeed, empirical testing of drawing, to-date, has explored the effects in isolation, rather than as a compent forming a package of support. It is possible that, as with the use of multiple Special Measures in courts in England and Wales, where witnesses often receive a combination of measures (Majeed-Ariss, Brockway, Cook \& White, 2019), a combination of strategies may be utlised in interviewing practice.

Recruiting specialist interviewing officers and Registered Intermediaries was challenging, as demonstrated by the modest sample size obtained for this study and in previous studies (e.g., Wheatcroft et al., 2014; Wright \& Powell, 2006). Similarly, these findings reflect only subjective interviewing practices, and those who took part were a self-selcting sample - a group who may have a particular interest in achieving best evidence. Upon investigation of objective data, for example, analysing video-recorded ABE interviews or ABE interview transcripts, a different picture may emerge (as per research conducted in New Zealand - see Wolfman et al., 2018). Greater understanding of real-life practice would allow for the development of more bespoke investigative interview training that is tailored to police officers' and Registered Intermediaries' needs, and moreover, those of the interviewee. 
RUNNING HEAD: PRACTITIONERS' USE OF DRAWING DURING INTERVIEWS

\section{Conclusion}

These findings provide new insight into practitioners' use and perceptions of a specific interview technique, which goes some way to bridging the knowledge gap between empirical evidence and practice. For instance, this study has demonstrated that drawing is perceived as an effective interviewing tool, and one that is regularly used by both police officers and Registered Intermediaries during investigative interviews with vulnerable witnesses. It is clear from the results that practitioners use drawing in different ways, with no consistent approach being apparent. The importance of establishing the ways in which this tool is most effective, and with which particular group(s) of vulnerable witnesses, is imperative in order to provide interviewers with empirically and theoretically sound practical guidance on this strategy.

Full word count: 6,014 
RUNNING HEAD: PRACTITIONERS' USE OF DRAWING DURING INTERVIEWS

\section{References}

Ackerman, B. P. (1985). Children's retrieval deficit. In C. J. Brainerd \& M. Pressley (Eds.), Basic processes in memory development: Progress in cognitive development research (pp. 1-46). New York: Springer-Verlag.

Ahern, E. C., Andrews, S. J., Stolzenberg, S. N., \& Lyon, T. D. (2018). The productivity of wh-prompts in child forensic interviews. Journal of interpersonal violence, 33(13), 2007-2015.

Arnold, M. M., \& Lindsay, D. S. (2002). Remembering remembering. Journal of Experimental Psychology: Learning, Memory \& Cognition, 28, 521-529.

Barlow, C. M., Jolley, R. P., \& Hallam, J. L. (2011). Drawing as memory aids: Optimising the drawing method to facilitate young children's recall. Applied Cognitive Psychology, 25(3), 480-487.

Bjorklund, D. (1987). How age changes in knowledge base contribute to the development of children's memory: An interpretive review. Developmental Review, 7(2), 93-130.

Brainerd, C. J., Reyna, V. E., Howe, M. L., \& Kingma, J. (1990). The development of forgetting and reminiscence. Monographs of the Society for Research in Child Development, 55, 3-4.

Brown, D. A., \& Lamb, M. E. (2015). Can children be useful witnesses? It depends how they are questioned. Child Development Perspectives, 9(4), 250-255.

Boucher, J. (1981). Memory for recent events in autistic-children. Journal of Autism and Developmental Disorders, 11, 293-301.

Boucher, J., \& Lewis, V. (1989). Memory impairments and communication in relatively able autistic children. Journal of Child Psychology and Psychiatry, 30, 99-122. 
RUNNING HEAD: PRACTITIONERS' USE OF DRAWING DURING INTERVIEWS

Bowler, D. M., Gaigg, S., \& Lind, S. (2011). Memory in autism: Binding, self, and brain. In I. Roth \& P. Rezaie, Researching the autism spectrum disorder: Contemporary perspectives (pp. 316-346). Cambridge: Cambridge University Press.

Brown, D. A., Brown, E. J., Lewis, C. N., \& Lamb, M. E. (2018). Narrative skill and testimonial accuracy in typically developing children and those with intellectual disabilities. Applied cognitive psychology, 32(5), 550-560.

Brown, D., Lewis, C., Stephens, E., \& Lamb, M. (2017). Interviewers' approaches to questioning vulnerable child witnesses: The influences of developmental level versus intellectual disability status. Legal and Criminological Psychology, 22, 332-349.

Bruck, M., Melnyk, L., \& Ceci, S. J. (2000). Draw it again Sam: The effect of drawing on children's suggestibility and source monitoring ability. Journal of Experimental Child Psychology, 77, 169-196.

Bukatko, D., \& Daehler, M. W. (1998). Child development: A thematic approach ( $3^{\text {rd }}$ ed.). Boston: Houghton Mifflin Company.

Butler, S., Gross, J., \& Hayne, H. (1995). The effect of drawing on memory performance in young children. Developmental Psychology, 31(4), 597-608.

Cederborg, A. C., \& Lamb, M. (2008). Interviewing alleged victims with intellectual disabilities. Journal of Intellectual Disability Research, 52, 49-58.

Cooper, P., \& Mattison, M. L. A. (2017). Intermediaries, vulnerable people and the quality of evidence: An international comparison of three versions of the English intermediary model. International Journal of Evidence and Proof. Available at: http://journals.sagepub.com/doi/pdf/10.1177/1365712717725534

Cooper, P., Dando, C. J., Ormerod, T. C., Mattison, M. L. A., Marchant, R., Milne, R., \& Bull, R. (2018). One step forward and two steps back? The "20 Principles" for questioning vulnerable victims and witnesses and the lack of an evidence-based approach. The 
RUNNING HEAD: PRACTITIONERS' USE OF DRAWING DURING INTERVIEWS

International Journal of Evidence and Proof. Available at: http://journals.sagepub.com/doi/full/10.1177/1365712718793435

Criminal Justice Joint Inspection (2014). Achieving best evidence in child sexual abuse cases: A joint inspection. London: HMCPSI Publications.

Dando, C. J. (2013). Drawing to Remember: External support of older adults' eyewitness performance. PloSOne, 8, e69937.

Dando, C. J., Wilcock, R., Behnkle, C., \& Milne, R. (2011). Modifying the cognitive interview: Countenancing forensic application by enhancing practicability. Psychology, Crime \& Law, 17, 491-511.

Dando, C. J., Wilcock, R., \& Milne, R. (2008 ${ }^{\mathrm{a}}$ ). Victims and witnesses of crime: Police officers' perceptions of interviewing practices. Legal and Criminological Psychology, 13, 59-70.

Dando, C. J., Wilcock, R., \& Milne, R. $\left(2008^{\mathrm{b}}\right)$. The cognitive interview: Inexperienced police officers' perceptions of their witness/victim interviewing practices. Legal and Criminological Psychology, 13, 59-70.

Dando, C. J., Wilcock, R., \& Milne, R. (2009ª). Novice police officers' application of the cognitive interview procedure. Psychology, Crime \& Law, 15, 679-696.

Dando, C. J., Wilcock, R., \& Milne, R. $\left(2009^{b}\right)$. The efficacy of a modified mental reinstatement of context procedure for frontline police investigators. Applied Cognitive Psychology, 23, 138-147.

Dando, C. J., Ormerod, T. C., Cooper, P., Marchant, R., Mattison, M., Milne, R., \& Bull, R. (2018). No evidence against Sketch Reinstatement of Context, Verbal Labels or the use of Registered Intermediaries for children with Autism Spectrum Disorder: Response to Henry et al.(2017). Journal of autism and developmental disorders, 48(7), 2593-2596. 


\section{RUNNING HEAD: PRACTITIONERS' USE OF DRAWING DURING INTERVIEWS}

Driessnack, M. (2005). Children's drawings as facilitators of communication: a metaanalysis. Journal of Pediatric Nursing, 20(6), 415-423.

Elo, S., \& Kyngäs, H. (2008). The qualitative content analysis process. Journal of advanced nursing, 62(1), 107-115.

Eichenbaum H, \& Cohen NJ. (2001). From Conditioning to Conscious Recollection: Memory Systems of the Brain: Memory Systems of the Brain. Oxford University Press: Oxford.

Eysenck, M. W. (1992). Anxiety: The cognitive perspective. Hove, England: Erlbaum.

Eysenck, M. W., Derakshan, N., Santos, R., \& Calvo, M. G. (2007). Anxiety and cognitive performance: attentional control theory. Emotion, 7(2), 336.

Fisher, R. P. (1995). Interviewing victims and witnesses of crime. Psychology, Public Policy, and Law, 1(4), 732.

Gee, S., \& Pipe, M. E. (1995). Helping children to remember: The influence of object cues on children's accounts of a real event. Developmental Psychology, 31(5), 746-758.

Gross, J., \& Hayne, H. (1998). Drawing facilitates children's verbal reports of emotionally lade events. Journal of Experimental Psychology: Applied, 4(2), 163-179.

Gross, J., Hayne, H, \& Poole, A. (2006). The use of drawing in interviews with children: A potential pitfall. In J. R. Marrow (Ed.), Focus on child psychology research (pp. 119144). New York, NY: Nova.

Henry, L. A., Crane, L., Nash, G., Hobson, Z., Kirke-Smith, M., \& Wilcock, R. (2017). Verbal, visual, and intermediary support for child witnesses with autism during investigative interviews. Journal of autism and developmental disorders, 47(8), 2348-2362.

Henry, L. A., Crane, L., Nash, G., Hobson, Z., Kirke-Smith, M., \& Wilcock, R. (2018). Response to 'No Evidence Against Sketch Reinstatement of Context, Verbal Labels or Registered Intermediaries'. Journal of autism and developmental disorders, 1-3.

Hershkowitz, I., Lamb, M. E., Orbach, Y., Katz, C., \& Horowitz, D. (2012). The development 
RUNNING HEAD: PRACTITIONERS' USE OF DRAWING DURING INTERVIEWS

of communicative and narrative skills among preschoolers: Lessons from forensic interviews about child abuse. Child Development, 83, 611-622.

Howe, M. L., \& O’Sullivan, J. T. (1997). What children's memories tell us about recalling out childhoods: A review of storage and retrieval processes in the development of longterm retention. Developmental Review, 17(2), 148-204.

Johnson, M., Magnussen, S., Thoresen, C., Lønnum, K., Burrell, L. V., \& Melinder, A. (2015). Best practice recommendations still fail to result in action: A national 10- year followup study of investigative interviews in CSA cases. Applied Cognitive Psychology, 29(5), 661-668.

Katz, C., \& Hamama, L. (2013). "Draw me everything that happened to you": Exploring children's drawings of sexual abuse. Children and Youth Services Review, 35(5), 877882.

Krähenbühl, S. J. (2011). Effective and appropriate communication with children in legal proceedings according to lawyers and intermediaries. Child Abuse Review, 20, 407420.

Lamb, M. L. A., LaRooy, D., Malloy, L., \& Katz, C. (Eds.). (2011). Children's testimony: A handbook of psychological research and forensic practice (2nd ed.). West Sussex, England: Wiley.

Lamb, M. E., Orbach, Y., Hershkowitz, I., Esplin, P. W., \& Horowitz, D. (2007). A structured forensic interview protocol improves the quality and informativeness of investigative interviews with children: A review of research using the NICHD investigative interview protocol. Child Abuse \& Neglect, 31(11), 1201-1231.

Lee, J. K., Wendelken, C., Bunge, S. A., \& Ghetti, S. (2016). A time and place for everything: Developmental differences in the building blocks of episodic memory. Child development, 87(1), 194-210. 
RUNNING HEAD: PRACTITIONERS' USE OF DRAWING DURING INTERVIEWS

Lloyd, M. E., Doydum, A. O., \& Newcombe, N. S. (2009). Memory binding in early childhood: Evidence for a retrieval deficit. Child Development, 80(5), 1321-1328.

Macleod, E., Gross, J., \& Hayne, H. (2016). Drawing conclusions: The effect of instructions on children's confabulation and fantasy errors. Memory, 24(1), 21-31.

Majeed-Ariss, R., Brockway, A., Cook, K., \& White, C. (2019). 'Could do better': Report on the use of special measures in sexual offences cases. Criminology \& Criminal Justice, 1748895819840396.

Mattison, M. L. A., Dando, C. J., \& Ormerod, T. (2015). Sketching to remember: Episodic free recall task support for child witnesses and victims with autism spectrum disorder. Journal of Autism and Developmental Disorders, 45(6), 1751-1765.

Mattison, M., Dando, C. J., \& Ormerod, T. C. (2018). Drawing the answers: Sketching to support free and probed recall by child witnesses and victims with autism spectrum disorder. Autism, 22(2), 181-194.

Millward, C., Powell, S., Messer, D., \& Jordan, R. (2000). Recall for self and other in autism: Children's memory for events experienced by themselves and their peers. Journal of Autism and Developmental Disorders, 30, 15-28.

Milne, R., \& Bull, R. (2006). Interviewing victims of crime, including children and people with intellectual disabilities. In M. R. Kebbell \& G. Davies (Eds.), Practical psychology for forensic investigations and prosecutions. Chichester: Wiley.

Ministry of Justice. (2011). Achieving best evidence in criminal proceedings: Guidance on interviewing victims and witnesses, and guidance on using special measures. London: Author.

Ministry of Justice. (2015). Registered Intermediary Procedural Guidance Manual. London: Author.

Murphy, G. H., \& Clare I. C. H. (2006). The effect of learning disabilities on witness testimony. In A. Heaton-Armstrong, E. Shepherd, G. Gudjonsson, D. Wolchover (Eds.), Witness testimony: psychological, investigative and evidential perspectives (pp. 43- 
RUNNING HEAD: PRACTITIONERS' USE OF DRAWING DURING INTERVIEWS

59). Oxford: Oxford University Press.

Patterson, T., \& Hayne, H. (2011). Does drawing facilitate older children's reports of emotionally laden events? Applied Cognitive Psychology, 25(1), 119-126.

Paz-Alonso, P. M, Ghetti, S., Matlen, B. J., Anderson, M. C., \& Bunge, S. A. (2009). Memory suppression is an active process that improves over childhood. Frontiers in Human Neuroscience, 3, 24.

Pipe, M. E., Lamb, M. E., Orbach, Y., \& Esplin, P. W. (2004). Recent research on children's testimony about experienced and witnessed events. Developmental Review, 24, 440468.

Pipe, M. E., \& Salmon, K. (2009). Dolls, drawing, body diagrams, and other props: Role of props in investigative interviews. In K. Kuehnle \& M. Connell (Eds.), The evaluation of child sexual abuse allegations: A comprehensive guide to assessment and testimony (pp. 365-395). Hoboken, NJ: Wiley \& Sons Inc.

Poole, D. A., \& Lamb, M. E. (1998). Investigative interviewing of children. Washington: American Psychological Association.

Powell, M. B., Fisher, R. P., \& Wright, R. (2005). Investigative interviewing. In N. Brewer \& K. D. Williams, Psychology and Law: An empirical perspective (pp. 11-42). New York, NY: The Guilford Press.

Powell, M. B., Hughes-Scholes, C. H., \& Sharman, S. J. (2012). Skill in interviewing reduces confirmation bias. Journal of Investigative Psychology and Offender Profiling, 9(2), 126-134.

Salmon, K. (2001). Remembering and reporting by children: The influence of cues and props. Clinical Psychology Review, 21, 267-300.

Salmon, K., Roncolato, W., Gleitzman, M. (2003). Children's reports of emotionally laden events: Adapting the interview to the child. Applied Cognitive Psychology, 17(1), 65- 


\section{RUNNING HEAD: PRACTITIONERS' USE OF DRAWING DURING INTERVIEWS}

79.

Saywitz, K. J. (1995). Improving children's testimony: The question, the answer, and the environment. In M. S. Zaragoza, J. R. Graham, G. C. N. Hall, R. Hirschman \& Y. S. Ben-Porath (Eds.), Memory and testimony in the child witness (pp. 36-49). Thousand Oaks, CA: Sage.

Sluzenski, J., Newcombe, N., \& Kovacs, S. L. (2006). Binding, relational memory, and recall of naturalistic events: A developmental perspective. Journal of Experimental Psychology: Learning, Memory, \& Cognition, 32, 89-100.

Strange, D., Garry, M., \& Sutherland, R. (2003). Drawing out children's false memories. Applied Cognitive Psychology, 17(5), 607-619.

Tulving, E. (1985). How many memory systems are there? American Psychologist, 40(4), 385398.

Tulving, E., \& Thomson, D. M. (1973). Encoding specificity and retrieval processes in episodic memory. Psychological Review, 80(5), 352-373.

Victims' Commissioner. (2018). A voice for the voiceless: the Victims' Commissioner's review into the provision of Registered Intermediaries for children and vulnerable victims and witnesses. London: The Office of the Victims' Commissioner.

Wesson, M., \& Salmon, K. (2001). Drawing and showing: Helping children to report emotionally laden events. Applied Cognitive Psychology, 15(3), 301-319.

Wheatcroft, J. M., Wagstaff, G. F., \& Russell, K. (2014). Specialist police interviewer perceptions of the enhanced cognitive interview: Usefulness, confidence and witness reliability. Police Practice and Research, 15(6), 505-518.

White, S. W., Oswald, D., Ollendick, T., \& Scahill, L. (2009). Anxiety in children and adolescents with autism spectrum disorders. Clinical psychology review, 29(3), 216229. 
RUNNING HEAD: PRACTITIONERS' USE OF DRAWING DURING INTERVIEWS

Wolfman, M., Brown, D., \& Jose, P. (2016). Talking past each other: Interviewer and child verbal exchanges in forensic interviews. Law and Human Behavior, 40(2), 107.

Wolfman, M., Brown, D., \& Jose, P. (2018). The use of visual aids in forensic interviews with children. Journal of applied research in memory and cognition, 7(4), 587-596.

Wright, R., \& Powell, M. B. (2006). Investigative interviewers' perceptions of their difficulty in adhering to open-ended questions with child witnesses. International Journal of Police Science \& Management, 8(4), 316-325.

Wyman, J. D., Lavoie, J., \& Talwar, V. (2018). Best practices for interviewing children with intellectual disabilities in maltreatment cases. Exceptionality, 1-18.

Zhang, Y., \& Wildemuth, B.M. (2009). Qualitative analysis of content. In B. Wildemuth (Ed.), Applications of Social Research Methods to Questions. Portland: Information and Library Book News. 